part of the Henry Draper Memorial, it is suggested that it be designated as the Draper Catalogue. In order to produce the spectra, a prism 8 inches square and having a refracting angle of $13^{\circ}$, was fastered in front of the object-glass, with its refracting angle placed perpendicular to the earth's axis. The spectra obtained have been conveniently arranged in classes indicated by the letters $\mathrm{A}$ to $\mathrm{Q}$. Of these, $\mathrm{A}, \mathrm{B}, \mathrm{C}$, and $\mathrm{D}$ indicate varieties of Secchi's first type, $\mathrm{E}$ to $\mathrm{L}$ varieties of the second type, $\mathrm{M}$ the third type, and $\mathrm{N}$ the fourth type. The letter $\mathrm{O}$ is used for stars whose spectra consist mainly of bright lines, and the letter $\mathrm{P}$ is reserved for planetary nebulæ. The classes $\mathrm{O}$ and $\mathrm{P}$ closely resemble each other, and are regarded by Prof. Pickering as a fifth type of spectrum. All spectra not included in these classes are indicated by the letter Q. Viewed as the result of a preliminary survey of the types of the photographic spectra of stars, the catalogue is of the highest importance. But it is to the discussion of individual lines, which is to follow in another volume, that we have to look for detailed information which may improve our knowledge of stellar constitution.

SOlar ObSERVATIONS From January to MarCh i89i.In Comptes rendus, No. 19 (May I I, I89I), Prof. Tacchini gives the following account of solar activity during the first three months of this year.

Observations of spots and faculæ have been made on 64 days, viz. 16 in January, 26 in February, and 22 in March. The results obtained are :-

\begin{tabular}{|c|c|c|c|c|c|c|}
\hline \multirow[b]{2}{*}{1891.} & \multicolumn{2}{|c|}{ Relative frequency } & \multicolumn{2}{|c|}{ Relative magnitude } & & \multirow{2}{*}{$\begin{array}{c}\text { Number } \\
\text { of } \\
\text { groups } \\
\text { per day }\end{array}$} \\
\hline & $\begin{array}{c}\text { of } \\
\text { spots. }\end{array}$ & $\begin{array}{l}\text { of days } \\
\text { without } \\
\text { spots. }\end{array}$ & $\begin{array}{l}\text { of } \\
\text { spots. }\end{array}$ & $\begin{array}{c}\text { of } \\
\text { faculæ. }\end{array}$ & & \\
\hline & I 56 & . 0.30 . & I8 & $16: 88$ & $\ldots$ & I. $3^{8}$ \\
\hline & $\ldots 2 \cdot 3 \mathrm{I}$ & $\ldots 0.15$ & ... $24 \% 4$ & $\ldots 89 \cdot 62$ & $\ldots$ & $2 \cdot 38$ \\
\hline & $\ldots \mathrm{I} \cdot 27$ & $\ldots 0.14$ & .. Ir 9 r & $\ldots 4 I \cdot 82$ & $\ldots$ & $\mathrm{I} \cdot 45$ \\
\hline
\end{tabular}

The following are the results of observations of hydrogen prominences :-

r89. $\begin{gathered}\text { Number } \\ \text { of days of } \\ \text { observation }\end{gathered}$

\begin{tabular}{ccccc}
\multicolumn{4}{c}{ Prominences } \\
$\begin{array}{c}\text { Mean } \\
\text { number. }\end{array}$ & & $\begin{array}{c}\text { Mean } \\
\text { height. }\end{array}$ & & $\begin{array}{c}\text { Mean } \\
\text { extension }\end{array}$ \\
$4 \cdot 62$ & $\ldots$ & $36^{\prime \prime} \cdot 9$ & $\ldots$ & $\mathbf{1} \cdot 3$ \\
$7 \cdot 55$ & $\ldots$ & $44 \cdot 1$ & $\ldots$ & $\mathbf{1} \cdot 8$ \\
$6 \cdot 12$ & $\ldots$ & $40 \cdot 1$ & $\ldots$ & $\mathbf{1} \cdot 5$
\end{tabular}

$\begin{array}{lllllllll}\text { January } & \ldots & \mathbf{1 3} & \ldots & 4 \cdot 62 & \ldots & 36 \cdot 9 & \ldots & \mathbf{1} \cdot 3 \\ \text { February } & \ldots & \mathbf{2 2} & \ldots & 7 \cdot 55 & \ldots & 44 \cdot \mathbf{1} & \ldots & \mathbf{1} \cdot 8 \\ \text { March } & \ldots & \mathbf{1} 7 & \ldots & 6 \cdot 1 \mathbf{2} & \ldots & 40 \cdot \mathbf{r} & \ldots & \mathbf{1} \cdot 5\end{array}$

When these numbers are compared with those obtained for the last three months of 1890 , a marked increase is apparent. In addition to this the results obtained for spots, faculæ, and prominences indicate that a secondary maximum of solar activity occurred during the month of February.

The Constant of Aberration.-A short time ago MM. Lowy and Puiseux described the principle of their new method of studying annual aberration and the general conclusions deduced from the observations made last year (see NATURE, vol. xliii. p. 498). In Comptes rendus, No. 20 (May 19) they give a detailed account of the modus operandi, and the numerical values obtained by the observation of two groups of four stars. The mean of all the observations gives for the constant of aberration the value $20^{\prime \prime} \cdot 447 \pm 0^{\prime \prime} \cdot 024$.

\section{ANIMAL LIFE ON A CORAL REEF.}

I $N$ nearly all the shallow waters of the tropical seas there is an abundant fauna, but nowhere is there such a crowd of marine animals of all kinds as there is in the region that extends from the growing edge of the coral reef to a depth of some ro or 15 fathoms beyond it. This may be due to the fact that in this region there is plenty of light and heat, no great or sudden changes of temperature, or of the chemical composition of the water, and there is an abundant food supply brought by tidal currents from the surface of the ocean. Here it is, then, that we find the richest fauna. Here it is that the struggle for existence is most severe, and here it is that the animals are protected and concealed by the most pronounced marks and colours, and provided by Nature with various forms of armour, stings and spines to defend them in the battles with their enemies.

One of the most interesting results of this severe struggle for

I Abstract of Lecture by Dr. S. J. Hickson, delivered at the London Institution, January 22, I $89 \mathrm{r}$

NO. I I 26 , VOL. 44$]$ existence, or perhaps it would be more correct to say of the large number of species competing for existence, is the important faunistic difference that may be observed between one reef and another-nay, indeed, between one part of a reef and another part of the same reef.

Darwin long ago pointed out that in the struggle for existence a very slight advantage gained by any one of the competing species may entirely alter the whole aspect of the field; and it follows that a very slight though constant difference in the physical conditions, such, for example, in the case of coral reefs, as rapidity of tidal currents, amount of surf or character of the shore rocks, may completely change the characteristics of the fauna. There are, it is true, some genera and species that are apparently found on all the reefs, such as Tubipora and Madrepora, but every reef has its own peculiar characters, and a naturalist never feels when he is examining one that he has seen something exactly like it on any previous occasion.

The majority of the corals that are found on the reefs of North Celebes belong to two great orders-the Zoantharia and Alcyonaria. The prevailing colour of the living Zoantharia is dull greeny-brown. The tentacles and the oral disks, and in some cases the growing or younger branches as a whole, may be very brightly coloured. White, pink, emerald green, violet, and blue, are colours frequently met with in different parts of the Zoantharian colony. The colours of the Alcyonarians may be due to the bright red, yellow, or purple spicules, or to the rich brown or green colour of the soft parts. There is very considerable variation in the colour of the soft parts of the Alcyonaria. The tentacles of the polyps of Tubipora, for example, may be any shade between bright green and pinkishbrown. A species of Sarcophytum, again, common on the shores of Celebes, showed green and greenish-yellow and yellow examples within the same half-mile of reef. All of these coral colours, with the exception of the colour of the spicules mentioned above, are soluble in spirit, the soft parts becoming, after prolonged immersion in this fluid, pale brown. The alcohol extracts of a considerable number of corals have now been submitted to spectrum analysis, and the bands they exhibit show close affinities with vegetable chlorophyll.

There is no experimental evidence at present that proves that the colours of the corals, nor, indeed, of the sponges, are either protective or warning in function. It seems much more probable that these brilliant colours represent different stages in the building up or breaking down of some complex chemical substance that is always present in marine zoophytes, and performs some important physiological function.

Besides the numerous sponges, corals, holothurians, mollusks, \&c., that are attached to the bottom or creep but slowly from place to place, the numerous species of swimming animals that are capable of active movements in pursuit of prey, or escaping from their enemies, must be considered as part of the fauna of the coral reef. These include fishes, cephalopods, and crustacea, and those of them that seem to live habitually among the corals of the reef are characterized by the possession of very curious spots or stripes and very brilliant colours.

Soon after my arrival in Talisse a large lobster was brought to me marked by broad transverse bands of blue and white; a large Squilla is not uncommon marked with similar bands of white and deep purple, and the little prawn Stenopus hispidus, that I found in a tidal pool close to a reef, has bands of red and white. The cephalopods have also peculiar markings. One specimen that I found, Octopus lunulatus, had large blue spots over its body and arms. The fishes, again, are marked with spots and stripes of various kinds and many brilliant colours.

Without going too deeply into the argument, we are justified in saying that these animals are so marked and coloured because they live among the brilliant surroundings of the coral reef; or, to put it in another way, animals similarly organized and of similar habits would be at a disadvantage on the coral reefs if they were not so marked and coloured. The other fishes of the tropics do not possess these curious and beautiful characters; the sharks, bonitos, flying fishes, herrings, and others that do not live habitually on the coral reefs are not unlike in general colour and ornamentation the fish of temperate seas. Again, the crustacea and fish of the tropical rivers and lakes are not as a rule characterized by any peculiar colouring or marking. These peculiarities, then, are not directly due to the high temperature and bright light of the tropics, but they are due to the character of the surroundings.

Most of the colours must be considered to be concealment 
colours. Stenopus hispidus, though so very conspicuous when taken out of the water, was extremely difficult to see in the pool where I found it. I should, in all probability, have failed to notice it, had I not quite unintentionally and blindly touched it with my stick. Like all animals protected by concealment colours, it remained perfectly motionless when alarmed. When looking down on to the growing edge of a reef from a boat on a calm day, it is very difficult at first to see anything but the corals and sponges. After a time, when the eyes become more accustomed to the light, the fish may be distinguished. Those that are coloured bluz are much less readily seen than the gold, yellow, and red varieties; but an examination of the fish that I caught myself, and were caught for me by the natives, showed that the fish in which blue is the prevailing colour are much more frequent in the very shallow water, while those that were caught in water from $\mathbf{1} 5$ to 20 fathoms were more frequently red or yellow. The blue colour seems to be a protection for the fish from air-breathing enemies-the eagles, ospreys, and hawks -and as these enemies can only approach them from above, the colours are frequently confined to the dorsal sides. The red and yellow colours of the fish seem to be a protection from animals, such as the sharks, perch, and other carnivorous fish, that approach them from the deeper waters beyond the reefs. Thus red and yellow fishes rarely have these colours confined to the upper sides, and many of the blue fishes are coloured red or yellow vent rally.

It is difficult to frame any general rule to account for the curious distribution of the colours of these animals in spots and stripes. Speaking in very general terms, for there are many exceptions, the fish that browse on the corals, possessing small mouths and chisel-shaped teeth (such as the Chrotodons, Trigger fish, and Surgeons), are striped ; those that feed on other fish, and have large mouths armed with carnivorous teeth, such as the Serranidæ, are spotted.

The only example of what appears to be a warning colour that I have noticed occurs in connection with the spines on the tails of certain Surgeons and Trigger fish. Acanthurus achiliis, for example, has a uniform purple colour, but there is a bright red patch surrounding the formidable tail spines that give these fish the name of Surgeons. Similar warning colours are very pronounced also in Naseus unicornis and Naseus lituratus, and in some of the Balistidæ.

\section{WASHINGTON MAGNETIC OBSERVATIONS, I $886 .^{1}$}

THIS volume contains the results that have been obtained from the magnetic observations taken at the Naval Observatory during the years 1888 and 1889 . The instruments with which they were made were, in the year 1887 , placed in their respective buildings that had been erected for that purpose by the Bureau of Navigation. In the construction of these buildings the greatest care was taken to insure the complete elimination of local disturbances. No iron or any magnetic material was used at all, and the fastenings, \&c., were entirely of copper, brass, and wood; even the stoves, in which only wood was burnt, were of soap-stone, with copper pipes.

The instruments that were employed consisted of a declinometer, theodolite, portable magnetometer, dip.circle, a set of self-recording magnetographs, a seismoscope, and seismograph; each of them, with the exception of the last two mentioned, being set on piers based on concrete, and in no way connected with the floors of the buildings. To complete the equipment, a compass-testing stand is placed on a pier north of the theodolite, and is capable of motion in an east and west direction. By means of an arm carrying two prisms that have adjusting screws, the opposite marks on the compass card can be placed in the field of view of the theodolite when the latter is directed on the prisms. All the observations, which are represented in tabular form, denote the results that have been obtained after applying all necessary corrections. The tables include, among others, the mean hourly values of the horizontal and vertical force for each month of 1889 , and of the declination for each month of 1888 and 1889 , the last of which are taken from the monthly curves; declination ordinates for each hour, in minutes of arc taken from daily declination traces; hourly values of horizontal

${ }^{1}$ Appendix I.-“" Magnetic Observations.”. By Ensign J. A. Hoogewerff, U.S. Navy. (Washington: Government Printing Office, r8go.)

NO. I I 26 , VOL. 44$]$ and vertical force in absolute measure with all corrections; observations of horizontal intensity and dip, with a summary of disturbances in declination which differed two minutes or more from the mean monthly curve.

No less important is the series of the fourteen large plates at the end of the volume. The first shows the way that the daily photographic traces of declination, horizontal and vertical force are recorded; while the second illustrates the mean diurnal variation of the magnetic elements for the year 1889 . In this latter plate the curve that gives the integration of these elements -that is, that gives the mean diurnal total force-brings out the fact that in every twenty-four hours there are two maxima and two minima, these latter two occurring between midnight and noon ( $75^{\text {th }}$ meridian mean time).

Plates iii. to vi. inclusive show the traces of the monthly composite curves of declination for the two years.

In Plates vii. to xiv. most interesting comparison is made of the disturbed days of declination taken from observations at Washington, Los Angeles (California), Toronto (Canada), and Pawlowsk (Russia): the curves are all computed for the same time (i.e. for the $75^{\text {th }}$ meridian west of Greenwich), and reduced to the same length of base line. Although on the whole the curves show a more or less equal variation, yet there are some cases in which a decided local variation has taken place. For instance, on January 20 , between the hours of noon and four o'clock (75th meridian time), the magnetic declination at Washington, Los Angeles, and Toronto, shows only slight variations, while at Pawlowsk the disturbance is in comparison quite large. Another very interesting case happens on March 17 , when the curves traced at Washington and Toronto are quite similar to each other, but different from those traced at the other two places, the curve showing the magnetic disturbances in declination at Pawlowsk being very similar to that indicating the horizontal force at Washington.

\section{UNIVERSITY AND EDUCATIONAL INTELLIGENCE.}

CAMBRIDGE. - The subject of the Rede Lecture, to be given by Sir Alfred Lyall on June 17, is "Natural Religion in India."

The General Board of Studies have again brought forward proposals for the increase of the stipends paid to University Lecturers and Demonstrators in Natural Science, which had to be postponed last year owing to want of funds.

Mr. A. Hutchinson, Demonstrator of Chemistry in Caius College, has been recognized as a Teacher of Chemistry with reference to the regulations for medical degrees.

A Syndicate is proposed by the Council of the Senate for the purpose of considering whether any alternative for Greek should be permitted in the Previous Examination. This is sure to rouse much agitation, but it may be hoped that the long-vexed question will at length be settled in a liberal sense.

Another Syndicate is to consider the office of Superintendent of the Museums of Zoology and Comparative Anatomy, about to be vacated by Mr. J. W. Clark, Registrary. Some rearrangement of the cluties, \&c., is considered desirable.

\section{SCIENTIFIC SERIALS}

American fournal of Science, May.-On the relationship of the Pleistocene to the pre-Pleistocene formations of the Mississippi basin, south of the limit of glaciation, by T. C. Chamberlain and R. D. Salisbury.-On certain measures of the intensity of solar radiation, by William Ferrel. The author shows that many measures of the intensity of solar radiation are of uncertain value. He specially discusses M. Crova's curves of the relative intensities of solar radiation, obtained at Montpellier with a modified form of the thermopile, called the registering. actinometer.--Geological age of the Saganaga syenite, by Horace V. Winchell.-On a self-feeding Sprengel pump, by H. L. Wells. - Contributions to mineralogy, No. 5o, by F. A. Genth ; with crystallographic notes by S. L. Penfield and L. V. Pirsson. The composition and habits of the following minerals are given : three new varieties of axinite, eudialyte, and monticellite, and titanite from Magnet Cove, Arkansas. - 